\title{
Loss of heterozygosity at the mannose 6-phosphate/insulin-like growth factor 2 receptor locus: a frequent but late event in adrenocortical tumorigenesis
}

\author{
Sophie Leboulleux, Véronique Gaston, Nathalie Boulle, Yves Le Bouc and Christine Gicquel \\ Laboratoire d'Explorations Fonctionnelles Endocriniennes, Hôpital Trousseau, AP-HP, Paris, France \\ (Correspondence should be addressed to C Gicquel, Laboratoire d'Explorations Fonctionnelles Endocriniennes, Hôpital d'enfants Armand Trousseau, \\ 26 Avenue Arnold Netter, 75012 Paris, France; Email: christine.gicquel@trs.ap-hop-paris.fr)
}

\begin{abstract}
Objective: Recent studies have pointed to the role of the IGF system in adrenocortical tumorigenesis. The IGF-II gene is overexpressed in malignant adrenocortical tumors and its proliferative effects are mediated by the type-1 IGF receptor (IGF1R). The mannose 6-phosphate/IGF2 receptor (M6P/IGF2R) plays a key role in regulating cell growth, by ensuring the clearance and inactivation of IGF-II and facilitating activation of the growth inhibitor, transforming growth factor $\beta$ (TGF $\beta 1$ ). The M6P/ IGF2R has been implicated as a tumor suppressor gene in various human tumors.

Methods: The purpose of this study was to determine if the M6P/IGF2R is involved in adrenal tumorigenesis. Two polymorphisms in the $3^{\prime}$ untranslated region of M6P/IGF2R were used to screen a large series of 76 sporadic adrenocortical tumors for loss of heterozygosity (LOH) by PCR amplification of DNA. Tumors were classified into three groups based on pathological features: benign tumors $(n=25)$, suspect tumors $(n=22)$ and malignant tumors $(n=29)$.

Results: $\mathrm{LOH}$ at the M6P/IGF2R locus was detected in 15 of 57 (26\%) informative tumors and was more frequent in malignant tumors (58\%) than in benign and suspect tumors (9 and $13 \%$ respectively).

Conclusion: These findings provide evidence that LOH at the M6P/IGF2R locus is a frequent event in adrenocortical tumors and support the hypothesis that it may function as a tumor suppressor gene in adrenocortical tumorigenesis.
\end{abstract}

European Journal of Endocrinology 144 163-168

\section{Introduction}

Adrenocortical tumors are rare and the pathogenesis is still poorly understood (1-3). Some data, such as clonal analysis, have suggested that adrenal tumorigenesis is a multistep process with a sequential progression from normal to adenomatous and eventually malignant cells $(4,5)$. Indeed, molecular studies of adrenocortical tumorigenesis have implicated genetic alterations in sporadic adrenocortical tumors and recent progress has resulted in the definition of several genetic markers. It is clear that some of these markers are strongly and specifically associated with the malignant phenotype. Abnormalities of the imprinted $11 \mathrm{p} 15$ region, $17 \mathrm{p} 13$ loss of heterozygosity $(\mathrm{LOH})$, 2p16 LOH and 11q13 LOH are all highly specific for malignant adrenocortical tumors $(2,3)$.

The insulin-like growth factor (IGF) system is involved in adrenocortical tumorigenesis. Dysregulation of the imprinted $11 \mathrm{p} 15$ region, resulting in the overexpression of IGF-II, has been implicated in the malignant transformation of adrenocortical tumors. Overexpression of IGF-II has indeed been demonstrated in about $90 \%$ of malignant adrenocortical tumors, but has not been detected in benign tumors (6). The overexpression of the insulin-like growth factor-I receptor (IGF1R), which mediates the proliferative effects of both IGF-I and IGF-II, has also been described in malignant adrenocortical tumors (7). In addition, using the adrenocortical H295R tumor cell line, we have shown that the proliferative effects of IGF-II are mediated by the IGF1R (8). Finally, high levels of IGFbinding protein-2 (IGFBP2), which regulates the proliferative effects of IGF-II, are associated with malignancy in sporadic adrenocortical tumors (9).

The mannose-6-phosphate/insulin-like growth factor 2 receptor (M6P/IGF2R), is a multi-ligand binding glycoprotein with a crucial role in regulating cell growth. It inactivates the growth factor IGF-II and mediates the activation of the growth inhibitor, transforming growth factor $\beta$ (TGF $\beta 1)(10,11)$. Mice lacking functional M6P/IGF2R are up to $30 \%$ larger 
Table 1 Features at presentation of 76 patients with sporadic adrenocortical tumors.

\begin{tabular}{lccc}
\hline & $\begin{array}{c}\text { Benign tumors } \\
(n=25)\end{array}$ & $\begin{array}{c}\text { Suspect tumors } \\
(n=22)\end{array}$ & $\begin{array}{c}\text { Malignant tumors } \\
(n=29)\end{array}$ \\
\hline Age (years; median/range) & $52(27-81)$ & $36(20-67)$ & $44(16-79)$ \\
Sex (F/M) & $22 / 3$ & $18 / 4$ & $20 / 9$ \\
Clinical features & & & 21 \\
$\quad$ Endocrine symptoms & 20 & 12 & 2 \\
$\quad$ Hypertension & 1 & 4 & 6 \\
$\quad$ Others & 4 & 6 & 5 \\
Functional status & 20 & 9 & 1 \\
$\quad$ Glucocorticoid only & 0 & 2 & 2 \\
$\quad$ Mineralocorticoid only & 1 & 2 & 4 \\
$\quad$ Sex steroids only & 3 & 4 & 4 \\
$\quad$ Mixed & $17(9-141)$ & 5 & $400(24-3600)$ \\
$\quad$ Nonfunctional & & $30(8-400)$ & \\
\hline
\end{tabular}

than their wild-type littermates and have high levels of circulating IGF-II (12-14). This growth increase can be fully attributed to high IGF-II levels because this phenotype is not seen in IGF2R mice that also lack functional IGF-II or IGF1R $(13,14)$.

Evidence for an antiproliferative role of M6P/IGF2R is also provided by its frequent involvement in carcinogenesis. Indeed, deleterious abnormalities of the IGF2R gene (LOH, mis-sense mutation or microsatellite instability) have been described in various tumor types including breast carcinomas $(15,16)$ and hepatocellular carcinomas $(17,18)$. Human mis-sense mutations have been expressed in vitro and most display impaired binding of IGF-II (19). Dynamic functional evidence of a growth suppressive role for the receptor was further provided by sense and antisense transfection in choriocarcinoma (20) and colorectal carcinoma cells (21), both cell lines being dependent on IGF-II for proliferation.

Taking into account the role of M6P/IGF2R in IGF-II clearance, the frequency of LOH at the M6P/IGF2R locus in other tumor models, the occurrence of $\mathrm{LOH}$ at this locus in some benign hepatocellular tumors and the importance of the IGF system in adrenocortical tumorigenesis, we tested whether inactivation of the M6P/IGF2R gene was important in adrenocortical tumorigenesis and whether it was involved in early tumorigenesis.

\section{Patients and methods}

A total of 76 patients (16-81 years old; 16 men and 60 women) with sporadic adrenocortical tumors were included in this study. Hormonal status and the stage of the tumor as localized, regional or metastatic were evaluated as previously described (22). Histological features including high mitotic rate, atypical mitoses, high nuclear grade, low percentage of clear cells, necrosis, diffuse architecture of tumor, capsular invasion, sinusoidal invasion and venous invasion were carefully recorded. Tumors with none of these histological features were classified as benign. Localized tumors with 1-3 of these histological features were classified as suspect. Tumors with $>3$ of these features or documented metastasis or recurrence were classified as malignant tumors (23). Clinical, hormonal and pathological data are summarized in Table 1.

Twenty-five patients were diagnosed as having localized adrenocortical tumors (weight 9-141 g) strictly benign in histological appearance; $88 \%$ (22 of 25 ) of these patients had secreting tumors. Twenty-two patients were diagnosed as having suspect tumors (weight $8-400 \mathrm{~g}$ ); $77 \%$ (17 of 22 ) of these patients had secreting tumors. Twenty-nine patients were initially diagnosed as having adrenocortical carcinomas, 10 with metastases, 4 with regional invasion and 15 with localized disease but histological data suggestive of malignancy; $86 \%$ (25 of 29) of these patients had secreting tumors, most with mixed secretion. Tumor weights were between 24 and $3600 \mathrm{~g}$.

Tissue fragments, obtained during surgery, were immediately frozen in liquid nitrogen, and stored at $-80^{\circ} \mathrm{C}$ until DNA extraction. Control leukocyte DNA for reference was available for all patients.

\section{DNA extraction}

We isolated leukocyte and tumor DNA as described previously (24).

\section{LOH analysis}

PCR Two polymorphisms have been described close together in the $3^{\prime}$ untranslated region of the M6P/ IGF2R gene; a polymorphic dinucleotide repeat sequence (25) and a tetranucleotide deletion/insertion polymorphism (26). The two polymorphisms together give a heterozygosity frequency of $58 \%$ (26). We used fluorescent primers flanking the two polymorphisms to amplify by PCR a 158 to 168 bp fragment (GeneBank 
TTGCCGGCTGGTGAATTCAA ACAA CCTGCCCAA AGATTGATTT GTGTGTTTGT GTGTGTGTGT GTGTGTGTGTGTGTGTGTGT GAGTGGAGTT GAGGTGTCAG AGAAAATGAA TITITTCCAG ATTTGGGGTATAGGTCTCAT CTCTTCAGGT TCTCATGATA C

Accession number AF109291, nt 1183-1344; Fig. 1). We then investigated the frequency of $\mathrm{LOH}$ at this locus in patients with adrenocortical tumors. In brief, $500 \mathrm{ng}$ genomic DNA from normal (leukocyte) and tumor tissues was used for PCR in a final volume of $50 \mu \mathrm{l}$ of $5 \mathrm{mmol} / \mathrm{l} \quad \mathrm{NH}_{4} \mathrm{Cl}, \quad 1.5 \mathrm{mmol} / \mathrm{l} \quad \mathrm{MgCl}_{2}$, $0.2 \mathrm{mmol} / \mathrm{l} \mathrm{dNTP} \mathrm{mix}, 400 \mathrm{nmol} / \mathrm{l}$ forward $\left(5^{\prime} \mathrm{TTG}\right.$ CCG GCT GGT GAA TTC AA $\left.{ }^{3^{\prime}}\right)$ and reverse $\left({ }^{5^{\prime}}\right.$ GTA TCA TGA GAA CCT GAA GAG ${ }^{3^{\prime}}$ ) primers (26; Fig. 1) and 2.5 units Taq DNA polymerase (Perkin Elmer Corporation, Norwalk, CT, USA) in a Perkin Elmer 9600 thermocycler. The PCR conditions were as follows: after an initial $2 \mathrm{~min}$ denaturation step at $94{ }^{\circ} \mathrm{C}, 35$ amplification cycles were performed, each consisting of a $30 \mathrm{~s}$ denaturing step at $94^{\circ} \mathrm{C}$, a $30 \mathrm{~s}$ annealing step at $55^{\circ} \mathrm{C}$ and a $30 \mathrm{~s}$ elongation step at $72{ }^{\circ} \mathrm{C}$. Amplification was completed with a final incubation step at $72{ }^{\circ} \mathrm{C}$ for $7 \mathrm{~min}$.

Detection of polymorphisms The amplified PCR products were analysed using the automated ABI PRISM sequencer model 373 A Genetic Analyzer (PE Applied Biosystems, Foster City, CA, USA). In brief, $2.5 \mu \mathrm{l}$ deionized formamide was mixed with $0.5 \mu \mathrm{l}$ GeneScan-500 (TAMRA) size standards (PE Applied Biosystems), $0.5 \mu \mathrm{l} 2 \times$ Agarose loading buffer and $1 \mu \mathrm{l}$ PCR product diluted 1 in 10 or 1 in 20 , in a Genetic Analyzer sample tube. The samples were denatured by heating for $5 \mathrm{~min}$ at $90{ }^{\circ} \mathrm{C}$, chilled on ice, loaded on a $6 \%$ denaturing polyacrylamide sequencing gel and subjected to electrophoresis according to the manufacturer's protocol. Results were analysed with the Genescan PCR analysis software (version 1.2.2-1; PE Applied Biosystems).

In informative patients, allelic loss was determined by calculation of the ratio of the peak heights of normal and tumor alleles according to the following formula:

(peak height of leukocyte allele 2)/

(peak height of leukocyte allele 1)

(peak height of tumor allele 2)/

(peak height of tumor allele 1)

LOH was strongly indicated by ratios $<0.7$ or $>1.4$ (27). At least three independent sets of results were used to confirm $\mathrm{LOH}$ in each tumor. test. pattern. section.
Figure 1 Nucleotide sequence of the $3^{\prime}$ untranslated region of the M6P/IGF2R gene (GeneBank Accession number AF109291, nt 1183-1344). PCR primers are shown in bold and the two polymorphisms are underlined.

\section{Statistical analysis}

Association between tumor group and allelic status at the M6P/IGF2R was calculated using contingency table methods and tested for significance using a chi-square

\section{Results \\ LOH at the M6P/IGF2R locus}

Seventy-six tumors classified on the basis of histological features were analysed. A total of 57 of the 76 patients (75\%) (22 benign, 16 suspect and 19 malignant tumors) were informative for the polymorphisms studied (Table 2). Six alleles (158-168 bp) were observed and their frequency was as described previously (26).

A total of 15 of the 57 (26\%) tumors exhibited LOH at the M6P/IGR2R locus, with a ratio $<0.7$ or $>1.4$ (Fig. 2). LOH for the M6P/IGF2R gene was detected in all three groups of tumors. However, the frequency of LOH was much higher in malignant tumors $(58 \%$ of informative patients) than in benign and suspect tumors (9 and 13\% of informative patients respectively; $P=0.0006)$ (Table 2).

In malignant tumors, LOH was not correlated with tumor expansion because LOH occurred in 7 of 10 localized tumors, in 1 of 3 tumors with regional expansion and in 3 of 6 tumors with metastases. The presence of $\mathrm{LOH}$ was also not correlated with hormonal

\section{Discussion}

Dysregulation of the IGF system, and particularly overexpression of the IGF-II gene, is involved strongly in the malignant transformation of adrenocortical tumors $(6,8,9)$. Both in vivo and in vitro data strongly

Table 2 Frequency of M6P/IGF2R loss of heterozygosity in adrenocortical tumors.

\begin{tabular}{lccc}
\hline Histology & $\boldsymbol{n}$ & $\begin{array}{c}\text { Informative patients } \\
(n, \%)\end{array}$ & $\begin{array}{c}\text { LOH } \\
(n, \%)\end{array}$ \\
\hline Benign & 25 & $22(88 \%)$ & $2(9 \%)$ \\
Suspect & 22 & $16(73 \%)$ & $2(12.5 \%)$ \\
Malignant & 29 & $19(65.5 \%)$ & $11(58 \%)$ \\
Total & 76 & $57(75 \%)$ & $15(26 \%)$ \\
\hline
\end{tabular}

$\mathrm{LOH}$, loss of heterozygosity as determined by calculation of the ratio of the peak heights for normal and tumor alleles as described in the methods 

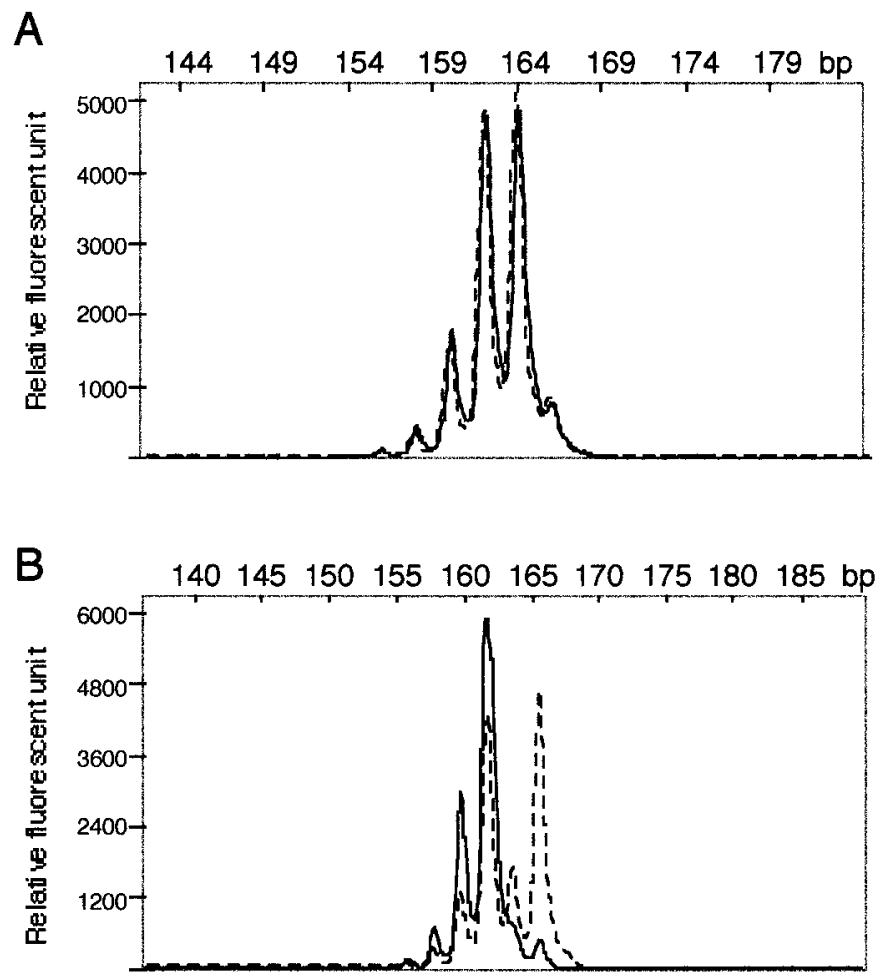

Figure 2 Leukocyte (dashed line) and tumoral (solid line) DNA patterns from representative informative patients without (A) and with (B) LOH at the M6P/IGF2R locus. bp, base pairs. suggest an antiproliferative function for the M6P/ IGF2R. Expression of M6P/IGF2R is often significantly reduced in a variety of tumors including breast cancers, gastrointestinal tumors and hepatocellular carcinomas (28-31). A high frequency of LOH with concomitant mutations in the remaining allele occurs at the M6P/ IGF2R locus in liver $(18,31-33)$ and breast tumors $(15,16,34)$. Moreover, $\mathrm{LOH}$ in adenomas and dysplastic liver lesions suggests that inactivation of the M6P/IGF2R may be an early event in hepatocellular carcinogenesis $(31,32)$. Introduction of the observed human mutations in M6P/IGF2R alters the binding of IGF-II $(19,35)$. Finally, sense and antisense transfection in cell lines dependent on IGF-II for proliferation has confirmed the antiproliferative function of M6P/IGF2R $(20,21)$.

In this study, we investigated whether inactivation of the M6P/IGF2R was important in adrenocortical tumorigenesis and could occur at early stages of tumorigenesis, thereby increasing the availability of the growth factor, IGF-II, which is essential for the proliferation of adrenal tumor cells (8). We investigated the M6P/IGF2R gene by comparing the allelic status of leukocyte and tumor DNA from 76 well-characterized adrenocortical tumors. A total of 57 of $76(75 \%)$ patients were informative for polymorphisms in the $3^{\prime}$ untranslated region of the M6P/IGF2R gene. This frequency was higher than the $58 \%$ heterozygosity rate previously reported (26). This difference probably results from the greater sensitivity of the method used in our study because the resolution of close bands is more precise in fluorescence-based PCR than in radioactive manual gel electrophoresis.

The $\mathrm{LOH}$ at the M6P/IGF2R locus was found in 26\% (15 of 57) of tumors. Like most genetic changes described to date in adrenocortical tumors $(2,3), \mathrm{LOH}$ at the M6P/IGF2R locus occurred more frequently in malignant tumors $(58 \%)$ than in benign $(9 \%)$ and suspect (i.e. premalignant; 13\%) tumors. These results did not provide evidence for involvement early in tumorigenesis but did show that M6P/IGF2R LOH was associated with the malignant phenotype as for $17 \mathrm{p} 13$, $11 \mathrm{q} 13,11 \mathrm{p} 15$ and 2p16 $\mathrm{LOH}(2,3)$.

If the M6P/IGF2R functions as a tumor suppressor gene, then the remaining allele should be inactivated in tumors exhibiting $\mathrm{LOH}$. Mutations in the remaining allele (including deletion in a region known to be prone to microsatellite instability) have been detected in liver and breast tumors (31). The frequency of mutations in the remaining allele has not yet been evaluated for adrenal tumors. Alternatively, aberrant imprinting may be responsible for inactivation of the remaining allele. The M6P/IGF2R is maternally imprinted in most mouse tissues and this pattern is maintained throughout development and in all the somatic tissues of the adult $(36,37)$. In humans, IGF2R imprinting is polymorphic, and monoallelic expression occurs in the preterm post-implantation embryo, but only in about $50 \%$ of individuals (38). Recently, Xu et al. (39) showed that abnormal fetal imprinting of the IGF2R, 
with marked repression of the paternal allele, occurs with a frequency of $50 \%$ in Wilms' tumors. This tumor model has mechanisms of pathogenesis in common with adrenocortical tumors. The high frequency of aberrant M6P/IGF2R imprinting in the kidneys of Wilms' tumor patients suggests that this may be a predisposing factor for tumorigenesis. This mechanism requires further investigation in adrenocortical tumors.

In conclusion, this study investigated $\mathrm{LOH}$ at the M6P/IGF2R locus in a large series of well-characterized human adrenocortical tumors and showed that the M6P/IGF2R gene may be involved mechanistically in adrenocortical tumorigenesis.

\section{Acknowledgements}

This work was supported by Assistance Publique Hôpitaux de Paris: Contrat de Recherche Clinique no. 97133, Paris VI University, Faculté Saint-Antoine (UPRES EA 1531), Association de Recherche contre le Cancer (no. 1364), INSERM (U515) and PHRC grant AOM 95201 for the Comete Network. SL was supported by grants from La Fondation pour la Recherche Médicale.

\section{References}

1 Latronico A \& Chrousos G. Extensive personal experience. Adrenocortical tumors. Journal of Clinical Endocrinology and Metabolism 199782 1317-1324.

2 Gicquel C, Le Bouc Y, Luton J \& Bertagna X. Adrenocortical carcinoma: pathogenesis and treatment. Current Opinion in Endocrinology and Diabetes 19985 189-196.

3 Kjellman M, Roshani L, Bäckdahl M \& Larsson C. Molecular genetics of adrenal cortical tumors. Current Opinion in Endocrinology and Diabetes 19996 70-76.

4 Gicquel C, Leblond-Francillard M, Bertagna X, Louvel A, Chapuis Y, Luton J et al. Clonal analysis of human adrenocortical carcinomas and secreting-adenomas. Clinical Endocrinology 1994 40 465-477.

5 Beuschlein F, Reincke M, Karl M, Travis W, Jaursch-Hancke C, Abdelhamid S et al. Clonal composition of human adrenocortical neoplasms. Cancer Research 199454 4927-4932.

6 Gicquel C, Raffin-Sanson M, Gaston V, Bertagna X, Plouin P, Schlumberger $M$ et al. Structural and functional abnormalities at 11 p 15 are associated with the malignant phenotype in sporadic adrenocortical tumors. Study on a series of 82 tumors. Journal of Clinical Endocrinology and Metabolism 199782 2559-2565.

7 Weber M, Auernhammer C, Kiess W \& Engelhardt D. Insulin-like growth factor receptors in normal and tumorous adult human adrenocortical glands. European Journal of Endocrinology 1997 $136296-303$.

8 Logié A, Boulle N, Gaston V, Perin L, Boudou P, Le Bouc Y et al. Autocrine role of IGF-II in proliferation of human adrenocortical carcinoma NCI H295R cell line. Journal of Molecular Endocrinology 199923 23-32.

9 Boulle N, Logié A, Gicquel C, Perin L \& Le Bouc Y. Increased levels of insulin-like growth factor-II (IGF-II) and IGF-binding protein-2 are associated with malignancy in sporadic adrenocortical tumors. Journal of Clinical Endocrinology and Metabolism 1998 83 1713-1720.

10 Kornfeld S. Structure and function of the mannose 6-phosphate / insulin-like growth factor II receptors. Annual Review of Biochemistry $199261307-330$.
11 Braulke T. Type-2 IGF receptor: a multi-ligand binding protein. Hormone Metabolism Research 199931 242-246.

12 Lau MM, Stewart CE, Liu Z, Bhatt H, Rotwein P \& Stewart CL. Loss of the imprinted IGF2/cation-independent mannose 6phosphate receptor results in fetal overgrowth and perinatal lethality. Genes and Development 19948 2953-2963.

13 Wang Z, Fung M, Barlow D \& Wagner E. Regulation of embryonic growth and lysosomal targeting by the imprinted IGF $2 / \mathrm{Mpr}$ gene. Nature $1994372464-467$.

14 Ludwig T, Eggenschwiler J, Fisher P, D’Ercole AJ, Davenport ML \& Efstratiadis A. Mouse mutants lacking the type 2 IGF receptor (IGF2R) are rescued from perinatal lethality in Igf2 and Igf1r null backgrounds. Developmental Biology 1996177 517-535.

15 Hankins GR, De Souza AT, Bentley RC, Patel MR, Marks JR, Iglehart JD et al. M6P/IGF2 receptor: a candidate breast tumor suppressor gene. Oncogene 199612 2003-2009.

16 Oates AJ, Schumaker LM, Jenkins SB, Pearce AA, DaCosta SA, Arun B et al. The mannose 6-phosphate/insulin-like growth factor 2 receptor (M6P/IGF2R), a putative breast tumor suppressor gene. Breast Cancer Research and Treatment $1998 \mathbf{4 7}$ 269-281.

17 Ozturk M. Genetic aspects of hepatocellular carcinogenesis. Seminars in Liver Disease 199919 235-242.

18 De Souza AT, Hankins GR, Washington MK, Orton TC \& Jirtle RL. $\mathrm{M} 6 \mathrm{P} / \mathrm{IGF} 2 \mathrm{R}$ gene is mutated in human hepatocellular carcinomas with loss of heterozygosity. Nature Genetics $199511447-$ 449.

19 Devi GR, De Souza AT, Byrd JC, Jirtle RL \& MacDonald RG. Altered ligand binding by insulin-like growth factor II/mannose 6- phosphate receptors bearing mis-sense mutations in human cancers. Cancer Research 199959 4314-4319.

20 O'Gorman DB, Costello M, Weiss J, Firth SM \& Scott CD. Decreased insulin-like growth factor-II/mannose 6-phosphate receptor expression enhances tumorigenicity in JEG-3 cells. Cancer Research $1999595692-5694$.

21 Souza RF, Wang S, Thakar M, Smolinski KN, Yin J, Zou TT et al. Expression of the wild-type insulin-like growth factor II receptor gene suppresses growth and causes death in colorectal carcinoma cells. Oncogene 199918 4063-4068.

22 Luton J, Cerdas S, Billaud L, Thomas G, Guilhaume B, Bertagna X et al. Clinical features of adrenocortical carcinoma, prognostic factors and the effect of mitotane therapy. New England Journal of Medicine 1990322 1195-1201.

23 Weiss L. Comparative histologic study of 43 metastasizing and nonmetastasizing adrenocortical tumors. American Journal of Surgical Pathology 1984 8 163-169.

24 Gicquel C, Bertagna X, Schneid H, Leblond-Francillard M, Luton J, Girard F et al. Rearrangements at 11 p15 locus and overexpression of Insulin like growth factor-II gene in sporadic adrenocortical tumors. Journal of Clinical Endocrinology and Metabolism $1994 \mathbf{7 8} 1444-1453$.

25 Goto J, Figlewicz DA, Marineau C, Khodr N \& Rouleau GA. Dinucleotide repeat polymorphism at the IGF2R locus. Nucleic Acids Research $1992 \mathbf{2 0} 923$.

26 Hol FA, Geurds MP, Hamel BC \& Mariman EC. Improving the polymorphism content of the $3^{\prime}$ UTR of the human IGF2R gene. Human Molecular Genetics 19921347.

27 Karnik P, Paris M, Williams BR, Casey G, Crowe J \& Chen P. Two distinct tumor suppressor loci within chromosome $11 \mathrm{p} 15$ implicated in breast cancer progression and metastasis. Human Molecular Genetics 19987 895-903.

28 Mathieu M, Vignon F, Capony F \& Rochefort H. Estradiol downregulates the mannose-6-phosphate/insulin-like growth factor-II receptor gene and induces cathepsin-D in breast cancer cells: a receptor saturation mechanism to increase the secretion of lysosomal proenzymes. Molecular Endocrinology $19915815-$ 822 .

29 Sue SR, Chari RS, Kong FM, Mills JJ, Fine RL, Jirtle RL et al. Transforming growth factor-beta receptors and mannose 6phosphate/insulin-like growth factor-II receptor expression in 
human hepatocellular carcinoma. Annals of Surgery $1995 \mathbf{2 2 2}$ 171-178.

30 Wang S, Souza RF, Kong D, Yin J, Smolinski KN, Zou TT et al. Deficient transforming growth factor-beta1 activation and excessive insulin-like growth factor II (IGFII) expression in IGFII receptor-mutant tumors. Cancer Research $1997572543-$ 2546.

31 Yamada T, De Souza AT, Finkelstein S \& Jirtle RL. Loss of the gene encoding mannose 6-phosphate/insulin-like growth factor II receptor is an early event in liver carcinogenesis. PNAS 199794 10351-10355.

32 De Souza AT, Hankins GR, Washington MK, Fine RL, Orton TC \& Jirtle RL. Frequent loss of heterozygosity on $6 \mathrm{q}$ at the mannose 6phosphate/insulin-like growth factor II receptor locus in human hepatocellular tumors. Oncogene 199510 1725-1729.

33 Piao Z, Choi Y, Park C, Lee WJ, Park JH \& Kim H. Deletion of the M6P/IGF2r gene in primary hepatocellular carcinoma. Cancer Letters 1997120 39-43.

34 Chappell SA, Walsh T, Walker RA \& Shaw JA. Loss of heterozygosity at the mannose 6-phosphate insulin-like growth factor 2 receptor gene correlates with poor differentiation in early breast carcinomas. British Journal of Cancer $1997 \mathbf{7 6}$ 1558-1561.
35 Byrd JC, Devi GR, de Souza AT, Jirtle RL \& MacDonald RG. Disruption of ligand binding to the insulin-like growth factor II/ mannose 6-phosphate receptor by cancer-associated mis-sense mutations. Journal of Biological Chemistry 199927424408 24416.

36 Barlow DP, Stoger R, Herrmann BG, Saito K \& Schweifer N. The mouse insulin-like growth factor type-2 receptor is imprinted and closely linked to the Tme locus. Nature 1991 349 84-87.

$37 \mathrm{Hu}$ JF, Oruganti H, Vu TH \& Hoffman AR. Tissue-specific imprinting of the mouse insulin-like growth factor II receptor gene correlates with differential allele-specific DNA methylation. Molecular Endocrinology 199812 220-232.

38 Wutz A, Smrzka OW \& Barlow DP. Making sense of imprinting the mouse and human IGF2R loci. Novartis Foundation Symposium $1998214251-259$.

$39 \mathrm{Xu}$ Y, Grundy P, Polychronakos C, Aberrant imprinting of the insulin-like growth factor II receptor gene in Wilms' tumor. Oncogene 199714 1041-1046.

Received 31 July 2000

Accepted 11 October 2000 